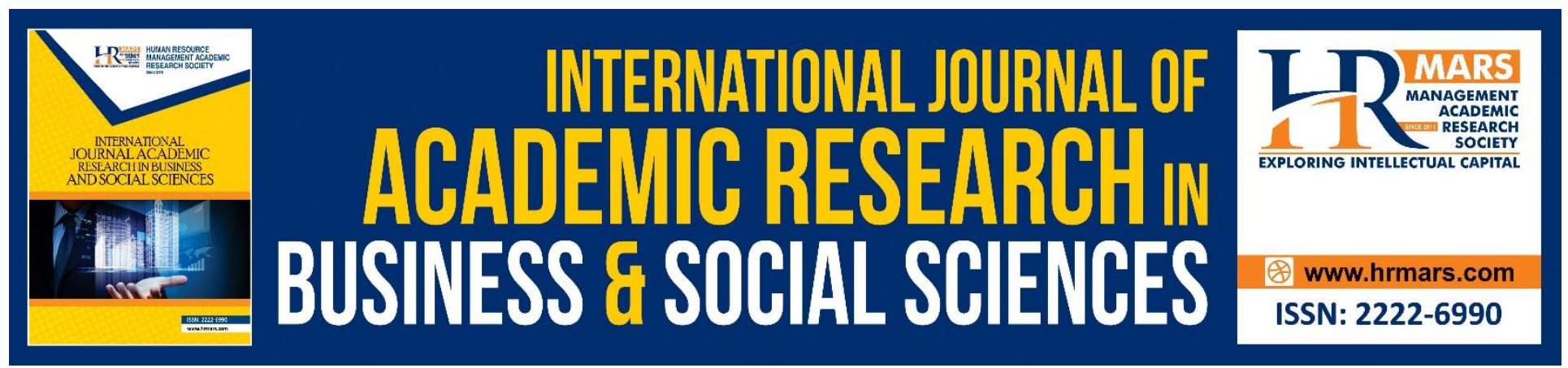

\title{
The Diversity of Recreational Knowledge in Sulalatus Salatin: Reflection of Intellectuality of Melaka Sultanate
}

Khairul Zainie Jasni \& Salmah Jan Noor Muhammad

To Link this Article: http://dx.doi.org/10.6007/IJARBSS/v8-i8/4941

DOI: $\quad 10.6007 /$ IJARBSS/v8-i8/4941

Received: 19 June 2018, Revised: 27 July 2018, Accepted: 29 July 2018

Published Online: 28 August 2018

In-Text Citation: (Jasni \& Muhammad, 2018)

To Cite this Article: Jasni, K. Z., \& Muhammad, S. J. N. (2018). The Diversity of Recreational Knowledge in Sulalatus Salatin: Reflection of Intellectuality of Melaka Sultanate. International Journal of Academic Research in Business and Social Sciences, 8(8), 819-827.

Copyright: (C) 2018 The Author(s)

Published by Human Resource Management Academic Research Society (www.hrmars.com)

This article is published under the Creative Commons Attribution (CC BY 4.0) license. Anyone may reproduce, distribute, translate and create derivative works of this article (for both commercial and non-commercial purposes), subject to full attribution to the original publication and authors. The full terms of this license may be seen

at: http://creativecommons.org/licences/by/4.0/legalcode

Vol. 8, No. 8, August 2018, Pg. 819 - 827

http://hrmars.com/index.php/pages/detail/IJARBSS

JOURNAL HOMEPAGE

Full Terms \& Conditions of access and use can be found at http://hrmars.com/index.php/pages/detail/publication-ethics 


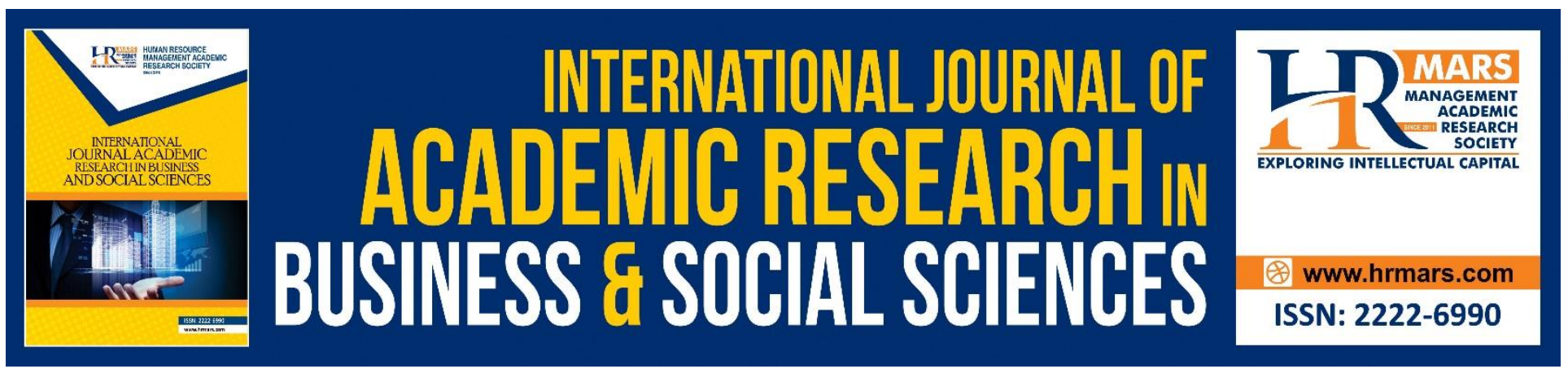

\title{
The Diversity of Recreational Knowledge in Sulalatus Salatin: Reflection of Intellectuality of Melaka Sultanate
}

\author{
Khairul Zainie Jasni \& Salmah Jan Noor Muhammad \\ Faculty of Modern Languages and Communication, Universiti Putra Malaysia, 43400, Serdang, \\ Malaysia
}

\section{Abstract}

The culture and the arts of the palace during the Malay sultanate of Melaka were very exclusive compared to the common people. The rulers of the kingdom must demonstrate the strength and greatness of all things in order to qualify themselves as rulers of the kingdom. Great rulers would then be able to expand its influence in the surrounding area. Therefore, the objective of this study is to identify and discuss the recreational knowledge in Sulalatus Salatin as a reflection of the intellect of the Malay rulers of Melaka. The method used is a text analysis to obtain the data of study. The result of the discussion found that there were various recreational practices conducted by the Melaka Malay rulers in the texts. The type of recreation performed is relaxed and rugged between are amongst that discussed in this article to demonstrate the power of the king in various skills besides highlighting the integrity of the government. The results of this study are also expected to benefit the community to know the leisure activities carried out by Melaka Malay rulers in the text of Sulalatus Salatin.

Keywords: Recreational, Intellectual, Malay, Sulalatus Salatin, Melaka

\section{Introduction}

The magnificence and greatness of the Malay kingdom of Melaka in the late 15th to early 16th century made Melaka a well-known kingdom in the archipelago. The sovereign king has a distinctive charisma to show his greatness and magnificence. Apart from their clothing, the activities of the Malay rulers are also distinguished from ordinary people. Hasanuddin Yusuf (2017) states that the grand Malay ruler is described as having his own kind of charisma as a head of state. As the head of the country, a sultan needs to an expert in leisure studies. Leisure studies that is mentioned is the specialisation, abilities and intelligence of the king in carrying out leisure activities. By having leisure studies, it helps to increase intellectuality Malay kings in carrying out their reign in their area. Other than that, in the book, Sulalatus Salatin, it will be used as the topic to discuss for the focus of the variety of leisure studies to increase the intellectuality Malacca Malay kings in Sulalatus Salatin. Sulalatus Salatin is the Malay's finest art that is brought as a world heritage of UNESCO. Sulalatus Salatin texts, an edition by A. Samad Ahmad (2015) published by Dewan Bahasa Dan Pustaka. The 
INTERNATIONAL JOURNAL OF ACADEMIC RESEARCH IN BUSINESS AND SOCIAL SCIENCES

Vol. 8, No. 8, August 2018, E-ISSN: 2222-6990 @ 2018 HRMARS

Sulalatus Salatin, also known as the Malay History, is a work that is the basis of the historiography of other Malay works (Salmah Jan Noor Muhammad, 2018). Sulalatus Salatin is a complete work in telling all the things in the Malay Archipelago such as law, diplomacy and weaponry. Norazimah Zakaria (2005) states that Sulalatus Salatin is a good synthesis genre and authored in Islamic times ie in the 15th century or 16th century AD causing a visibility on Hindu elements. This work was born from a pure intellectual Malay traditions at the Malay royal palaces. This study will use the text analysis method based on the copy of Sulalatus Salatin. The aspect that will be emphasized is the leisure conducted by the Malay rulers of Melaka. The leisure aspect analyzed will be explained based on the intelligence of the Malay rulers to set up strategies in conducting their recreational activities.

\section{Literatur Highlights}

This study is focused on the integrity of the Malay rulers in a variety of recreational sciences. A study of the recreational activities conducted by Ervina Alfian (2015) touched on archery sports which is an important sport for the Muslim community and should not be taken lightly. The study was supported by several researchers including Siti Zaleha Jorimai and Noor Fazrina Kamal (2009), Azharuddin Mohamed Deli (2014), which focused on the benefits of cognitive knowledge to individuals as well as the involvement of nobility and Malay elites involved in horse riding. Horse riding is seen as an expensive sport that is only played and owned by the kings only. Yanya, Asyraf Ab Rahman, Daud Ismail and Abdulsoma Thoralim (2018) state that during the Prophet Muhammad's horse riding and other sports activities were able to strengthen the physical, hone skills and improve individual capabilities.

Furthermore, Mohd Yusuf Abdullah (2015) states that Malays were able to adapt their lives to the environment and thus create a great race in the creation of diverse creative and innovative inventions without the need to learn a certain knowledge formally. Malays were skillful in exploring areas in the archipelago making the Malay kingdom known to China and Majapahit. In addition, Khazrin (2001) states that the ruling class were a part of travelers that travelled with aims at building the power of state governance and increasing the number of territorial powers.

Additionally, Ismail Hamid (1988) stated that the Malay rulers were very interested in chicken fights as recorded in older Malay texts. Muhammad Husnee Yanya, Asyraf Ab Rahman, Daud Ismail and Abdulsoma Thoralim (2018) also support that besides the chickens, other animals were also used as a fighting materials intended to be contested. Nurul Izzati Md. Mustafa et. al (2015) also discusses the role of animals other than aiming for the opening of new areas but also involved as sports and performances to celebrate the nobility or royalty as contained in the Misa Melayu.

Hinca Ip Pandjaitan (2011) also discusses that in the 14th century, sports were an entertaining and enjoyable activity for the nobles as part of a specific lifestyle as well as covering some of the popular and permanent games to be exclusive and aristocratic. Mohd Shukrey Ahmad and Kamariah Kamaruddin (2018) also touched on the goodness of leisure in Islam that puts the leisure as an important medium for the health of the human body to avoid any illness.

While the study of leisure activities has been widely discussed by previous researchers, this article focuses only on the recreational activities conducted by the Malay rulers as according to Sulalatus Salatin text. This article will identify and discuss the recreational sciences in Sulalatus Salatin as a reflection of the brilliance of Malay king of Melaka.

When looking through past studies, the researchers were more focused on the leisure activities that were carried out by the Malay society. Thus, this study will expand more on the research pertaining to leisure studies carried out by the officials. Other than that, Jelani Harun 
(2018:45) hoped that the study on leisure studies, more specifically in the traditional Malay literature should be done and needs to be discussed thoroughly and involves more sources in a whole. The pertaining to leisure is very necessary to value the role and its importance in a wider spectrum plus includes building personalities and characters of kings in ruling the country and the citizens in a whole. All in all, this article aims to investigate the leisure studies carried out by the Malay Malacca kings and to analyse the intellectuality of the kings in the leisure activities that were carried out.

\section{Research Methodology}

This study will be using the academic library research to obtain data for this study. There are four stages that are discussed, the selection stage, collection, analysis and formulation of data. At the stage of selection, the selection of Malay books is the paramount of importance in this stage. This stage is a very important to get the whole idea of the discussion. Other than that, in the collection of data stage, this study is carried out among books that are suitable with the research objectives. Reading the contents of the books will be thorough and recorded, especially the information pertaining to the topic of this study. Moreover, in the analysis of data stage, the matter that is focused in this stage is that the information obtained in second stage and is utilized as the main data to discuss the results of this study.

With this analysis of data, it resulted the discussion of the results of this study can be done to explain the psychology of sports and games in the traditional Malay books. The analysis of the behaviour in psychology of games and sports involves psychology aspects, social and emotion of an individual who is into the context of physical activities (Yusuff Ismail: 1993). This focus involves the needs of interest, behaviour, temperament and motivation of the participant from centring to the analysis of their performance. Every person who is involved in sports and games have interests, needs, emotion and lifestyle of their own. The involvement of leisure activities can help for selfimprovement, the decrease of pressure and acquire motivation competitively. This theory can be the outline in the analysis of data that are obtained in the book, Sulalatus Salatin.

\section{Findings/Discussions}

\section{Knowledge of Horsing}

Equestrian was a sport run by the royals. Siti Zaleha Jorimai and Noor Fazrina Kamal (2009) stated that horses in the tradition of older societies are said to be exclusively for the elites given the costs of such sports were quite expensive. The existence and importance of the horses in the Malay Sultanate of Melaka can be found in Sulalatus Salatin text as stated in the quotation below.

Hatta maka sekali persetua, kuda kenaikan Sultan Mansyur Syah jatuh ke pelindungan tahi, seorang pun tiada hendak menambat tali kepada kuda itu.

Setelah dilihat oleh Laksamana Hang Tuah orang yang beratus-ratus itu seorang pun tiada mahu mengambil kuda itu, maka Hang Tuah pun segera terjun ke dalam pelindungan itu, ditambatnya tali pada kuda itu......Setelah Sultan Mansyur Syah

melihat kuda baginda sudah naik itu, maka terlalulah sukacita baginda; beberapa puji baginda akan Hang Tuah, serta dianugerahi persalinan dengan sepertinya.

(Ahmad,2015: 130)

[One day Sultan Mansyur Syah's horse fell into a sewage, but none of his servants were able to tie the rope to the horse. After being seen by Hang Tuah, the people 
INTERNATIONAL JOURNAL OF ACADEMIC RESEARCH IN BUSINESS AND SOCIAL SCIENCES Vol. 8, No. 8, August 2018, E-ISSN: 2222-6990 C 2018 HRMARS

gathered but no one was able to save the horse, then Hang Tuah immediately jumped into the sewage and then pulled the horse with ropes... After being seen by Sultan Mansyur Syah that his horse was safe, he was pleased. He praised Hang Tuah and awarded Hang Tuah clothing as is the custom.]

(Ahmad, 2015: 130)

Based on the above excerpt, Sultan Mansyur Syah had his own horse. The king had his horse to carry out recreational activities. Horses are able to physically and mentally good for a one's health even to discipline themselves in everyday life. This is because, the horse is an animal that has a rough and wild nature. Sultan Mansyur Syah maintained a horse not only as a pet but also aimed to heal his body. In government, a king needs to improve his competence and make himself a person more sensitive to the environment. In conclusion, in addition to warfare, horses can also be a leisure tool that can strengthen the muscles, especially the spine and intellectual thinking of oneself.

\section{Knowledge of Travelling}

Traveling is a very synonymous activity among the ancient Malay community. According to the Indonesian Online Dictionary (2011), travelling means to sail in order to seek livelihoods along the region from one river to another. Whereas Kamus Dewan Fourth Edition (2011) dictionary defines wandering as sailing, walking or wandering to another country from its origin to seek other life. The travelers who were comprised from the Malay rulers have their own purpose. They were always trying to increase the strength of government based on the number of followers. According to Khazrin (2001), a group of monarchs and principals aimed at establishing diplomatic relations and marriages between the royalty among the royalists or state officials. Based on the texts of Sulalatus Salatin, traveling activities are carried out by the government either by the order of the king or for the purpose of opening a new kingdom.

Setelah itu, maka Sultan Mansyur Syah pun bersiaplah akan berangkat pergi ke

Majapahit serta menyuruh memberitahu ke Inderagiri pada Sultan Nara Singa, dan ke Tungkal pada Raja Merlang, dan ke Jambi pada Adipati Sira Sela Sida Raja, dan ke Palembang pada Demang Mangku Raja, di Lingga pada raja-raja itu pun datanglah, masing-masing ke kelangkapannya. Telah sudah berhadir sekaliannya maka Sultan Mansyur Syah pun berangkat ke Majapahit.

(Ahmad, 2015: 12)

[Afterwards, Sultan Mansyur Shah prepared to leave for Majapahit. He ordered so that Sultan Nara Singa in Inderagiri, King Merlang in Tungkal, Adipati Sira Sela Sida Raja in Jambi, Demang Mangku Raja in Palembang and kings in Lingga be told of this. So they came with their equipment. After everyone arrived, Sultan Mansyur Syah went to Majapahit.]

(Ahmad, 2015: 12)

Based on the above excerpt, the royalty would travel to conduct diplomatic relations with other countries. The royalty travelled with an aim at expanding the empire and colony. Traveling was seen as an attempt to open new settlements or land. Sultan Mansur Syah in the above passage travelled to Majapahit aiming to establish relations with Majapahit. The king's journey will be 
accompanied by royal advisors based on Malay customs. The passage also illustrates the greatness of the Malays as savvy sailors who mastered the knowledge of sailing. As long as the kingship left the country he ruled, the king would pass the responsibility of the ruler to the advisors who would replace the duties of the king and his country. This can help the king see his advisors' ability to be trusted throughout his absence in the country. In conclusion, traveling is a recreational activity in the active category because it requires energy and a great deal of time to be carried out.

\section{Knowledge of Hunting}

Hunting was a favorite activity of kings. During the hunting period, the responsibilities of state government will be passed to the trusted advisors. Most of the works of Malay historiography tell about the sovereignty and greatness of the king and the things that the king liked. Among them are hunting, war, marriage, customs, coronation and so on. In addition, hunting was also deemed capable of proving the bravery and dexterity of the king to hunt the game animals efficiently (King Hassan Raja Noor, 1972). The king's journey would be accompanied by an admiral who was responsible for his safety. Based on some examples in the texts of Sulalatus Salatin, the king of Melaka conducted hunting activities as according to the excerpt below.

Maka Sultan Maliku's-Salleh pun berfikir dalam hatinya hendak berbuat negeri akan tempat anakanda baginda; maka titah Sultan Maliku's-Salleh pada segala Orang Besar- besar, "Esok hari kita pergi berburu." Setelah pagi hari maka Sultan Maliku's-Salleh pun naiklah gajah yang bernama Permadewan itu, lalu berangkat ke seberang. Datang ke pantai, maka anjing yang bernama Pasai itu pun menyalak.

(A. Samad Ahmad, $2015: 58$ )

[Sultan Maliku's-Salleh thought in his heart to open a new state for his son. He immediately ordered all the chiefs, "Tomorrow we go hunting". In the morning, he rode on to the elephant named Peradewan and went across. Upon reaching the beach, a dog named Pasai barked. ]

(A. Samad Ahmad, 2015: 58)

Hunting activities were ran by the king aiming to open a new country. The example also tells the story of the opening of the country called Pasai in conjunction with the name of the puppet of Sultan Maliku's-Salleh. Hunting activities carried out by the king tell us that the origin of the country's opening also occurred due to hunting activities. In addition, the history of Melaka's name is also taken from the name of the Melaka tree where Parameswara rested. His hunting dog was kicked by an antler. The opening of the Melaka state is based on the greatness of the animals in the area.

\section{Knowledge of Chess}

The game of chess is one of the leisure activities found in the texts of Sulalatus Salatin. The strategy of playing chess is set in the discretion of the players' intelligence to defeat the opponent. The players must understand the steps of each chess piece. Chess playing skills need to be wise in determining how to play, the strategies and strive to survive. In the texts of Sulalatus Salatin, Tun Bahara was among the best in the game of chess. As such according to an example in the excerpt below. 
INTERNATIONAL JOURNAL OF ACADEMIC RESEARCH IN BUSINESS AND SOCIAL SCIENCES

Vol. 8, No. 8, August 2018, E-ISSN: 2222-6990 @ 2018 HRMARS

Maka segala orang yang tahu-tahu catur, semuanya alah olehnya, seorang tiada dapat melawan dia, melainkan Tun Pikrama, anak Bendahara Paduka Raja; ia juga yang dapat sedikit melawan Tun Bahara itu, tetapi jikalau lalai Tun Pikrama, digelarkan oleh Tun Bahara itu 'sayur keladi', dan jika Tun Bahara membuang sebijik bidak ujung jua pun, alah pula Tun Bahara oleh Tun Pikrama, itulah yang tahu bercatur.

(Ahmad, $2015:$ 154)

[All the clever ones playing chess were defeated by him and no one was able to beat him except Tun Pikrama son of Bendahara Paduka Raja. He could defeat Tun Bahara but if Tun Pikrama was negligent, he would be known Sayur Keladi. If Tun Bahara put down a chess piece, Tun Bahara would be defeated by Tun Pikrama. He is the wisest in playing Chess.]

(Ahmad, 2015: 154)

The son of the King's Treasurer was a part of the elites playing chess against Tun Bahara from Pasai. One of the greatness of the royalty leadership in Melaka sultanate is to set the strategy to defeat the enemy only by playing chess. Chess does not require a lot of physical moves but only requires cleverly set up strategies in the game.

\section{Knowledge of Entertainment}

The fourth edition of Kamus Dewan (2007) defines relaxation as relaxed to do anything freely without tension, relaxing and without pressure.

"Janganlah kamu larang, biarlah ia bermain." Maka Tun Bijaya Sura pun bermainlah sapu-sapu rengit. Maka Seri Betara pun bermainlah sapu-sapu rengit. Maka Seri Bijaya Sura pun tersenyum melihat pejenaka Tun Bijaya Sura itu; dalam hatinya berkata, "sangat bijaksana raja Melayu ini, semua hambanya cerdik belaka;

(Ahmad, 2015: 122)

["Do not be forbid, let them play ". Tun Bijaya Sura then played a game called sapu sapu rengit. Seri Betara Sura also played the game. Seri Bijaya Sura smiled at the jokes of Tun Bijaya Sura while in his heart he said "This Malay king must be smart because all his servants are smart;]

(Ahmad, 2015: 122)

Based on the excerpt above, King Majapahit was pleased to be entertained by a messenger from Melaka named Tun Bijaya Sura. Seri Betara was impressed with the intelligence of the Melaka messenger. This activity illustrates Seri Betara taking the time to see and watch Melaka envoys entertaining. Seri Betara was very impressed with the cleverness of Melaka people. Hence this would raise the greatness of the reign of the King of Melaka. This casual activity illustrates that the king also needed entertainment and relaxation to relieve the body and mind of the government responsibilities. This also proves that this entertaining activity could strengthen the relationship between Melaka and Majapahit. 


\section{Summary}

In summary, the leisure practices carried out by the Malay rulers were able to make Melaka a wellknown and magnificent country. The power of the Malay rulers is also described through its wise and obedient people towards the king. Generally, the equestrian knowledge among the rulers of the Malay kingdom of Melaka was much more favored than any other activity as the king had his own pet horses. The horses were not only signify the greatness of the elites but were also used as a recreational tool among the Malay rulers. Currently, horses are no longer the exclusive sport of kings because they are run by ordinary people. In 2017 Sultan Zainal Abidin proved that the greatness of the Malay rulers in horse riding was still relevant today when he won gold medal in the endurance event of the 29th SEA Games (Bernama, 2017).

\section{Conclusion}

The leisure practices carried out by Malay rulers of Melaka in the Sulalatus Salatin texts increased the integrity of the king in his reign. This study is expected to benefit the field of social sciences and can be highlighted to the public on the importance of recreational knowledge conducted by the ancient kings. Additionally, awareness of the community also needs to change the stigma that some recreational activities that are considered costly can actually be conducted by ordinary people. The greatness of the Malays in the texts of Sulalatus Salatin should be lessons to the Malays themselves and not just upholding pride in the history of the ancient. The sharpness of the minds of the Malay rulers of Melaka in governing was instrumental in order for that a kingdom be known and magnificent throughout the country. In addition, this study is also expected to benefit athletes not to see these activities solely as an excitement but they should look at the benefits. The study of recreational science should be carried out more widely to examine the intellectual elements contained in every activity carried out not only towards the body but also on human thinking.

\section{Corresponding Author}

Khairul Zainie Jasni

Universiti Putra Malaysia

43400 Serdang

Selangor Darul Ehsan

Malaysia

Email: khairulzainie@gmail.com

\section{References}

Azharudin M.D. (2014). Kuda dalam Masyarakat di Tanah Melayu pada Era Sebelum Merdeka. Jurnal Antarabangsa Dunia Melayu. 7 (2). 172-191.

Ervina, A. (2015). Pengaruh Islam di Dalam Sukan Memanah: Suatu Realiti di sebalik Kedudukannya sebagai Sukan Memanah dalam Isu-isu dan Cabaran Tamadun Islam. Universiti Malaya. Jabatan Sejarah \& Tamadun Islam

Hasanuddin, Y. (2017). Teknologi Kesultanan Melaka : Membongkar Keagungannya Berdasarkan Catatan Portugis. Melaka. Cintai Publication. 
INTERNATIONAL JOURNAL OF ACADEMIC RESEARCH IN BUSINESS AND SOCIAL SCIENCES

Vol. 8, No. 8, August 2018, E-ISSN: 2222-6990 @ 2018 HRMARS

Hinca, I.P XIII. (2011). Kedaulatan Negara Versus Kedaulatan FIFA dalam Kompetisi Sepakbola Profesional untuk Memajukan Kesejahteraan Umum. Jakarta. PT Gramedia Pustaka Utama.

Ismail, H. (1988). Masyarakat dan Budaya Melayu. Kuala Lumpur. Dewan Bahasa dan Pustaka.

Kamus Dewan Edisi Keempat. (2007). Kuala Lumpur. Dewan Bahasa dan Pustaka.

Khazrin, M. T. (2001) Peneroka Tanah dan Hutan pada Zaman Kolonial. Prosiding Persidangan Kebangsaan Pusat Pengajian Sosial, Pembangunan dan Persekitaran. Bangi. Universiti Kebangsaan Malaysia.

Mohd, S.A. dan Kamariah, K. (2018). Nilai Islam dalam Komik Majalah Dewan Pelajar. Jurnal Melayu. 17(1). 49-73

Mohd, Y. A. (2015). Bicara Dunia Melayu, Tradisi Pelayaran Melayu. Terengganu. Muzium Negeri Terengganu.

Muhammadhusnee, Y., Asyraf, A. R, Daud, I. \& Abdulsoma, T. (2018). Konsep Pertandingan Sukan Tradisional Menurut al-Quran dan al-Sunah di Selatan Thailand. Jurnal Islam dan Masyarakat Kontemporari. 16 (1), 72-85.

Norazimah, Z. (2005). Sejarah Melayu : Sebuah Genre Sintesis yang Baik bagi Memenuhi Tuntutan Moral Islam dan Aspek Pengawalan Politik. Jurnal Pengajian Melayu. 16(6). 319-334.

Salmah, J. N., Muhammad. (2018). Ilmu Diplomatik Melayu dalam Kesusasteraan Melayu Tradisional. Serdang. Universiti Putra Malaysia.

Shida, I., Nurbaidura, S. \& Badaruddin, M. (2013). Tradisi Merantau masyarakat Melayu Dahulu dan Sekarang : Suatu Perbandingan dalam Kearifan Tempatan:Pengalaman Nusantara Jilid 1 Berasal Dari Akar. Penang. Universiti Sains Malaysia.

Siti, Z. J. \& Noor, D. K. (2009, 7 Februari).Berkuda Bukan Sukan Mewah. Utusan Online. Retrived from

http://ww1.utusan.com.my/utusan/info.asp?y=2009\&dt=0207\&sec=Rekreasi\&pg=rk 01.htm 